The University of San Francisco

USF Scholarship: a digital repository@ Gleeson Library | Geschke Center

\title{
Thermodynamic Study of the Gaseous Molecules Al2N, AlN, and Al2N2 by Knudsen Cell Mass Spectrometry
}

Giovanni Meloni

University of San Francisco, gmeloni@usfca.edu

Karl A. Gingerich

Follow this and additional works at: http://repository.usfca.edu/chem_fac

Part of the Chemistry Commons

\section{Recommended Citation}

Meloni, G. and Gingerich, K. A. Thermodynamic study of the gaseous molecules Al2N, AlN, and Al2N2 by Knudsen cell mass spectrometry. The Journal of Chemical Physics, 113, 10978-10982 (2000).

This Article is brought to you for free and open access by the Chemistry at USF Scholarship: a digital repository @ Gleeson Library|Geschke Center. It has been accepted for inclusion in Chemistry Faculty Publications by an authorized administrator of USF Scholarship: a digital repository @ Gleeson Library | Geschke Center. For more information, please contact repository@usfca.edu. 


\title{
Thermodynamic study of the gaseous molecules $\mathrm{Al}_{2} \mathrm{~N}$, AIN, and $\mathrm{Al}_{2} \mathrm{~N}_{2}$ by Knudsen cell mass spectrometry
}

\author{
G. Meloni and K. A. Gingerich \\ Department of Chemistry, Texas A\&M University, P.O. Box 30012, College Station, Texas 77842-3012
}

(Received 6 July 2000; accepted 29 September 2000)

\begin{abstract}
The Knudsen effusion mass spectrometric method has been employed to measure the equilibrium partial pressures of the $\mathrm{Al}_{2} \mathrm{~N}$ molecule over the $\mathrm{AlN}-\mathrm{Au}$-graphite system. Theoretical computations were carried out to determine the structure, molecular parameters, and thermodynamic properties of $\mathrm{Al}_{2} \mathrm{~N}$. The partial pressures have been combined with the calculated thermal functions to determine the atomization enthalpy, $\Delta_{a} H_{0}^{o}$, and enthalpy of formation, $\Delta_{f} H_{298.15}^{o}$, in kJ mol${ }^{-1}$, of $783.2 \pm 15$ and $342.7 \pm 15$ for $\mathrm{Al}_{2} \mathrm{~N}$, respectively. Upper values for the dissociation energy of $\mathrm{AlN}$, $D_{0}^{o}(\mathrm{AlN}, g) \leqslant 368 \pm 15 \mathrm{~kJ} \mathrm{~mol}^{-1}$, and for the atomization enthalpy of $\mathrm{Al}_{2} \mathrm{~N}_{2}, \Delta_{a} H_{0}^{o}\left(\mathrm{Al}_{2} \mathrm{~N}_{2}, g\right)$ $\leqslant 1402 \mathrm{~kJ} \mathrm{~mol}^{-1}$ have been obtained. These results are discussed and compared with recent theoretical literature values. (C) 2000 American Institute of Physics. [S0021-9606(00)01448-3]
\end{abstract}

\section{INTRODUCTION}

Aluminum-nitrogen clusters have received increased attention in the last few years because of their potential use as precursors in the growth of new materials with uncommon properties, ${ }^{1}$ and because of gaining a better understanding of the fundamental mechanisms leading to the thin-film synthesis in order to optimize the deposition process. ${ }^{2}$

Aluminum nitride (AIN) is a useful material for substrates in microelectronics devices, due to its high thermal conductivity, very low electrical conductivity, moderately low dielectric constant, and a thermal expansion coefficient which is close to that of silicon. ${ }^{3.4} \mathrm{~A}$ recent study by Bhatti et $a l^{5}$ showed that the use of AIN thin films as piezoelectric coating enables higher optical phase response over a wider frequency range as compared to similar devices using $\mathrm{ZnO}$.

There are few experimental studies on gaseous aluminum nitrides. Gingerich ${ }^{6}$ observed for the first time the molecule $\mathrm{Al}_{2} \mathrm{~N}$ by Knudsen effusion mass spectrometry, and determined its atomization enthalpy, $\Delta_{a} H_{298.15}^{o}$, as 828 $\pm 21 \mathrm{~kJ} \mathrm{~mol}^{-1}$. He suggested the AlNAl arrangement of the atoms from the comparison of the enthalpies of atomization of $\mathrm{Al}_{2} \mathrm{~N}$ with those of $\mathrm{Si}_{2} \mathrm{~N}$ and $\mathrm{Al}_{2} \mathrm{O}$. Simmons and $\mathrm{McDonald}^{7}$ observed the emission spectrum of AlN in the visible region, and obtained the vibrational frequency of the AlN ground state as $747 \mathrm{~cm}^{-1}$. Andrews et al. ${ }^{8}$ used infrared matrix isolation spectroscopy to study the products of aluminum atoms reacting with dinitrogen. They identified $\mathrm{AlN}_{2}$, $\mathrm{Al}_{2} \mathrm{~N}, \mathrm{Al}_{2} \mathrm{~N}_{2}, \mathrm{AlN}_{3}$, and $\mathrm{Al}_{3} \mathrm{~N}$ molecules by nitrogen isotopic substitution and comparison with computed isotopic vibrational frequencies.

Several computational studies ${ }^{9-16}$ have been carried out on aluminum-nitrogen clusters to optimize their structures, to calculate the relative stability of different isomers, the vibrational frequencies and ionization energies, and to estimate their atomization energies.

In continuation of our recent investigations on small nitrogen containing group 13 and 14 clusters, ${ }^{17-21}$ we employed the Knudsen cell mass spectrometric method to de- termine the atomization energies and enthalpies of formation of the $\mathrm{Al}_{2} \mathrm{~N}$, AlN, and $\mathrm{Al}_{2} \mathrm{~N}_{2}$ molecules. We also performed theoretical computations of $\mathrm{Al}_{2} \mathrm{~N}$.

\section{THEORETICAL INVESTIGATIONS}

$A b$ initio calculations were carried out utilizing the GAUSSIAN 98 program package ${ }^{22}$ in order to gain information about the molecular parameters and physical-chemical properties of the $\mathrm{Al}_{2} \mathrm{~N}$ ground state.

The calculations were performed at the density functional level of theory using the Becke three-parameter exchange functional with the Lee, Yang, and Parr correlational functional (B3LYP). The basis set employed for this study was a correlated consistent polarized valence triple-zeta basis set, cc-pVTZ.

$A b$ initio calculations were performed on the three possible isomers of $\mathrm{Al}_{2} \mathrm{~N}$, two linear structures, $\mathrm{Al}-\mathrm{N}-\mathrm{Al}$ and $\mathrm{Al}-\mathrm{Al}-\mathrm{N}$, and a cyclic one. The results are listed in Table I. From the calculations the most stable isomer is found to have the linear symmetric structure with a ${ }^{2} \Sigma_{u}^{+}$electronic ground state. This result is also in agreement with experimental and theoretical results for similar molecules, $\mathrm{Si}_{2} \mathrm{~N},{ }^{23.24}$ and $\mathrm{B}_{2} \mathrm{~N},{ }^{25-28}$ which too have linear symmetric structures as the most stable ground state geometry. In Fig. 1 the potential energy of the ground state of $\mathrm{Al}_{2} \mathrm{~N}$ is plotted as a function of the $\mathrm{AlN}-\mathrm{Al}$ bond distance at the B3LYP/cc-pVTZ level of theory.

The asymmetric linear structure, $\mathrm{Al}-\mathrm{Al}-\mathrm{N}$, with a ${ }^{2} \mathrm{\Sigma}^{+}$ electronic ground state lies about $375 \mathrm{~kJ} \mathrm{~mol}^{-1}$ (31350 $\mathrm{cm}^{-1}$ ) above the symmetric $\mathrm{Al}_{2} \mathrm{~N}$ ground state, and the cyclic structure with the same electronic multiplicity as that of $\mathrm{Al}-\mathrm{N}-\mathrm{Al}$ is optimized as the linear symmetric one. The lowest energy cyclic structure has a ${ }^{4} B_{2}$ electronic state and lies about $237 \mathrm{~kJ} \mathrm{~mol}^{-1}\left(19810 \mathrm{~cm}^{-1}\right)$ above the ground state of the linear symmetric $\mathrm{Al}_{2} \mathrm{~N}$.

The vibrational frequencies for the three vibrational normal modes, the optimized molecular parameters, and the atomization enthalpies, $\Delta_{a} H_{0}^{o}$, of the $X^{2} \Sigma_{u}^{+}$state of the linear 
TABLE I. The optimized bond distances, vibrational frequencies, electron affinity (EA), ionization energy (IE), and atomization enthalpy $\left(\Delta_{u} H_{0}^{\circ}\right)$ of the ${ }^{2} \Sigma_{u}^{+}$ground sate of the linear symmetric $\mathrm{Al}_{2} \mathrm{~N}$ and of its isomers at the B3LYP/cc-pVTZ level of theory.

\begin{tabular}{cccccccccccc}
\hline \hline $\begin{array}{c}\text { Electronic } \\
\text { state }\end{array}$ & Symmetry & Total energy $^{\mathrm{a}}$ & $r_{\mathrm{Al}-\mathrm{N}^{\mathrm{b}}}$ & $r_{\text {Al-Al }}$ & $\alpha_{\text {AINAI }}$ & $\nu_{1}$ & $\nu_{2}$ & $\nu_{3}$ & $\mathrm{EA}^{\mathrm{c}}$ & IE & $\Delta_{u} H_{0}^{o d}$ \\
\hline${ }^{2} \Sigma_{u}^{+}$ & $D_{x h}(\mathrm{AlNAI})$ & -539.6634092 & 1.726 & & 180 & $527^{\mathrm{d}}$ & 94 & 1061 & 2.27 & 8.01 & 731.4 \\
${ }^{2} \Sigma^{+}$ & $C_{x_{v}}(\mathrm{AlAlN})$ & -539.5205276 & 1.692 & 2.723 & 180 & 251 & 29 & 872 & & & 359.8 \\
${ }^{4} B_{2}$ & $C_{2 v}\left(\mathrm{Al}_{2} \mathrm{~N}\right)$ & -539.5733202 & 1.817 & & 91.5 & $690^{\mathrm{f}}$ & 307 & 706 & & & 495.3 \\
\hline \hline
\end{tabular}

"The computed total energy is in hartree.

'The bond length is in $\AA$.

'EA and IE are in $\mathrm{eV}$.

${ }^{d} \Delta_{u} H_{0}^{o}$ is in $\mathrm{kJ} \mathrm{mol}^{-1}$.

${ }^{\mathrm{c}} \nu_{1}$ is the symmetric stretching $\left(\sigma_{R}\right), \nu_{3}$ the antisymmetric stretching $\left(\sigma_{u}\right)$, and $\nu_{2}$ the bending vibrational mode $\left(\pi_{u}\right)$, in $\mathrm{cm}^{-1}$.

${ }^{\prime} \nu_{1}$ is the symmetric stretching $\left(a_{1}\right), \nu_{3}$ the antisymmetric stretching $\left(b_{1}\right)$, and $\nu_{2}$ the bending vibrational mode $\left(a_{1}\right)$, in $\mathrm{cm}^{-1}$.

symmetric isomer and of the lowest lying electronic states of the other isomers of $\mathrm{Al}_{2} \mathrm{~N}$ are listed in Table I. For the most stable isomer the electron affinity (EA) and the ionization energy (IE) are also given. The computed EA, IE, and $\Delta_{a} H_{0}^{o}$ reported in Table I were corrected for the zero point energies (ZPE). Our computed values for the symmetric $\left(\sigma_{g}\right)$ and antisymmetric $\left(\sigma_{u}\right)$ stretching vibrational modes agree well with the corresponding experimental values of $957 \mathrm{~cm}^{-1}$ and $545 \mathrm{~cm}^{-1}$ by Andrews et al. ${ }^{8}$ The theoretical calculations by Andrews et al. ${ }^{8}$ at the B3LYP level of theory using 6-311 $+\mathrm{G}^{*}$ and cc-pVDZ basis sets give results consistent with ours.

In order to support our computations, we also calculated the bond distances, vibrational frequencies, electron affinity, ionization energy, and atomization enthalpy $\left(\Delta_{a} H_{0}^{o}\right)$ for the AlNC molecule at the same level of theory. The results of these calculations show good agreement with the experimental values of bond distances, ${ }^{29}$ vibrational frequencies, ${ }^{30}$ and atomization energy. ${ }^{20}$

\section{EXPERIMENTAL PROCEDURE}

The mass spectrometer and experimental procedures used for this work have been described previously. ${ }^{31}$ The sample of finely powdered AlN, graphite, and gold was vaporized from a high density graphite Knudsen cell. The measurements were performed following the investigation of the AlNC/AICN molecule, ${ }^{20}$ and divided into series 1 and series 2 , because of the different ionization energies used.

The cell was heated by radiation by a tungsten coil resistor and the temperatures were measured with a calibrated Leeds and Northrup optical pyrometer focused onto a black body hole at the bottom of the cell. The ions were produced with ionizing electrons and electron emission current of 30 $\mathrm{eV}$ and $1 \mathrm{~mA}$ for series 1 , and $15.5 \mathrm{eV}$ and $1 \mathrm{~mA}$ for series 2 . The acceleration voltage used was $3 \mathrm{kV}$; the electron multiplier was operated at $1.5 \mathrm{kV}$ for both series.

The ions pertinent to the present investigation were $\mathrm{Al}^{+}$, $\mathrm{Au}^{+}, \mathrm{AlAu}^{+}, \mathrm{AlNC} / \mathrm{AlCN}^{+}, \mathrm{Al}_{2} \mathrm{~N}^{+}$, and $\mathrm{AlN}^{+}$. The ions

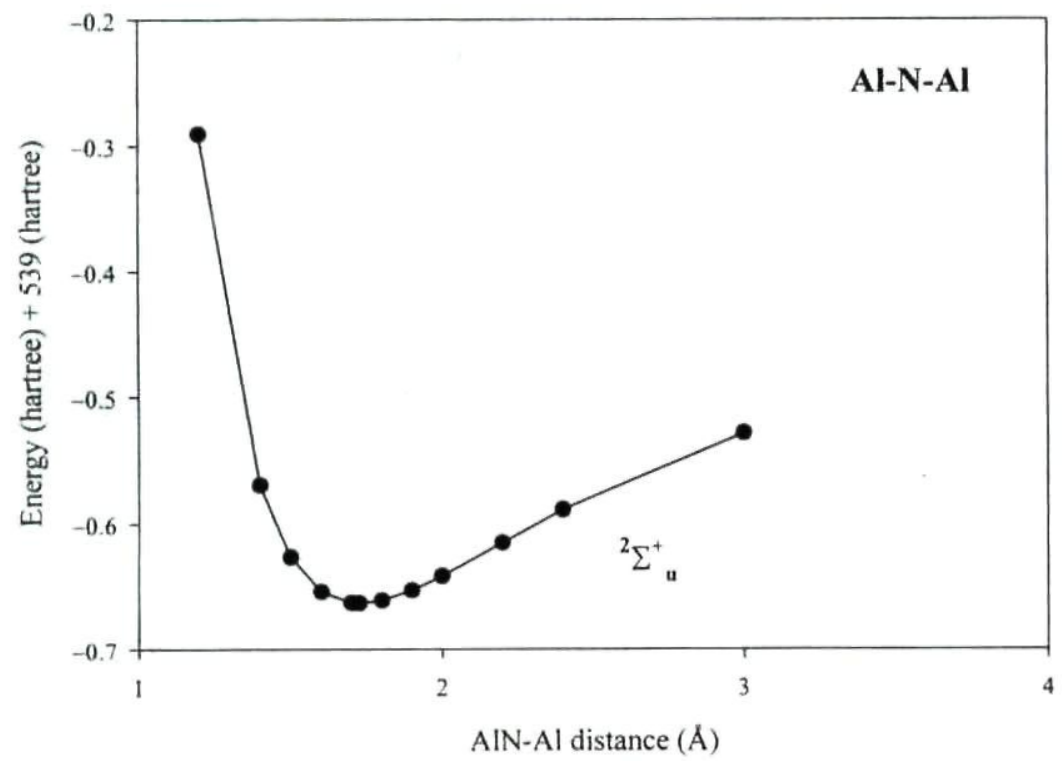

FIG. 1. Potential energy as a function of the AIN-Al distance of the ${ }^{2} \mathrm{\Sigma}_{u}^{+}$ground state of $\mathrm{Al}_{2} \mathrm{~N}$. calculated at the B3LYP/cc-pVTZ level of theory. 
TABLE II. Measured ion currents, in A, and third-law values, in $\mathrm{kJ} \mathrm{mol}^{-1}$, of the enthalpy of reactions (1) and (2), $\Delta, H_{0}^{o}$, and enthalpy of atomization, $\Delta_{a} H_{0}^{o}$. of $\mathrm{Al}_{2} \mathrm{~N}$.

\begin{tabular}{|c|c|c|c|c|c|c|c|c|c|}
\hline \multirow[b]{2}{*}{$T(\mathrm{~K})$} & \multicolumn{5}{|c|}{ Ion intensities } & \multirow{2}{*}{$\begin{array}{c}\Delta, H_{0}^{\circ} \\
\text { reaction } 1\end{array}$} & \multirow{2}{*}{$\Delta_{a} H_{0}^{o}$} & \multirow{2}{*}{$\begin{array}{c}\Delta_{r} H_{0}^{o} \\
\text { reaction } 2\end{array}$} & \multirow{2}{*}{$\Delta_{\mathrm{a}} H_{0}^{v}$} \\
\hline & $\mathrm{Al}_{2} \mathrm{~N}^{+}$ & $\mathrm{Al}^{+}$ & $\mathrm{AuAl}^{+}$ & $\mathrm{Au}^{+}$ & $\mathrm{AINC}^{+}$ & & & & \\
\hline \multicolumn{10}{|l|}{ Series 1} \\
\hline 1818 & $9.22 E-13$ & $1.13 E-7$ & $2.45 E-9$ & $8.70 E-10$ & $1.25 E-9$ & -35.6 & 803.5 & 319.2 & 793.2 \\
\hline 1862 & $1.50 E-12$ & $1.99 E-7$ & $3.40 E-9$ & $1.20 E-9$ & $2.89 E-9$ & -42.0 & 797.1 & 327.9 & 784.5 \\
\hline 1862 & $8.53 E-13$ & $2.02 E-7$ & $3.40 E-9$ & $1.20 E-9$ & $2.80 E-9$ & -50.3 & 788.8 & 336.9 & 775.5 \\
\hline 1857 & $7.29 E-13$ & $2.08 E-7$ & $4.44 E-9$ & $1.43 E-9$ & $2.99 E-9$ & -54.9 & 784.2 & 338.9 & 773.5 \\
\hline 1805 & $3.49 E-13$ & $9.74 E-8$ & $3.15 E-9$ & $1.10 E-9$ & $9.63 E-10$ & -46.2 & 792.9 & 329.3 & 783.1 \\
\hline \multirow[t]{2}{*}{1940} & $1.20 E-11$ & $7.16 E-7$ & $1.13 E-8$ & $2.75 E-9$ & $1.33 E-8$ & -40.6 & 798.5 & 328.4 & 784.0 \\
\hline & & & & & & $-44.9 \pm 7.0^{3}$ & $794.2 \pm 7.0$ & $330.1 \pm 7.1$ & $782.3 \pm 7.1$ \\
\hline \multicolumn{10}{|l|}{ Series 2} \\
\hline 1886 & $1.24 E-12$ & $3.12 E-07$ & $5.70 E-09$ & $1.03 E-09$ & $3.19 E-09$ & -53.4 & 786.5 & 339.8 & 772.6 \\
\hline 1907 & $1.58 E-12$ & $4.35 E-07$ & $6.70 E-09$ & $1.18 E-09$ & $4.79 E-09$ & -57.0 & 782.8 & 345.0 & 767.4 \\
\hline 1922 & $2.05 E-12$ & $5.61 E-07$ & $7.92 E-09$ & $1.36 E-09$ & $6.43 E-09$ & -58.3 & 781.5 & 347.5 & 764.9 \\
\hline \multirow[t]{2}{*}{1940} & $3.41 E-12$ & $6.79 E-07$ & $8.60 E-09$ & $1.43 E-09$ & $9.00 E-09$ & -56.6 & 783.2 & 345.5 & 766.9 \\
\hline & & & & & & $-56.3 \pm 2.1$ & $783.5 \pm 2.1$ & $344.5 \pm 3.3$ & $768.0 \pm 3.3$ \\
\hline
\end{tabular}

"The error terms are standard deviations.

were identified by their mass-to-charge ratio, isotopic abundance, and, where possible, by their ionization efficiency curves. At each measurement a movable slit was interposed into the molecular beam to distinguish between ions produced from species in the beam and from residual gases with the same mass-to-charge ratio in the ionization region of the mass spectrometer. The electron impact energy scale was calibrated against the first ionization potential of $\mathrm{Au}(9.22$ $\mathrm{eV})($ Ref. 32) and the appearance potential of $(8.1 \pm 0.5) \mathrm{eV}$ was measured for $\mathrm{Al}_{2} \mathrm{~N}$ by the extrapolated voltage differences method. ${ }^{33}$ The measured appearance potential agrees with our computed value of $8.01 \mathrm{eV}$ (see Table I), and with the generalized gradient approximation (GGA) value of 7.84 $\mathrm{eV} .{ }^{11}$ The ion current data of the species pertinent to this investigation are listed in Table II.

The ion intensities $I_{i}$ measured for the various species were converted into partial pressures by the relation $p_{i}$ $=k_{i} I_{i} T$, where $k_{i}=k /(\sigma n \gamma)$ is the pressure calibration constant, $k$ is the instrumental constant, $\sigma$ is the ionization cross section, $n$ is the isotopic abundance, and $\gamma$ is the multiplier gain. The instrumental constant was determined from the known $\operatorname{AlAu}(g)=\operatorname{Al}(g)+\operatorname{Au}(g)$ equilibrium, using the measured corresponding ion currents and the known dissociation energy, $D_{0}^{o}(\mathrm{AlAu}, g)=(322.2 \pm 6.3) \mathrm{kJ} \mathrm{mol}^{-1} \cdot{ }^{34}$ The resulting instrumental constant, in bar $\mathrm{A}^{-1} \mathrm{~K}^{-1}$, is 26.6 for series 1 , and 24.3 for series 2 . The uncertainty of $k$ is estimated to be about $20 \%$.

\section{RESULTS AND DISCUSSION}

\section{$\mathrm{Al}_{2} \mathrm{~N}$}

For the determination of the enthalpy of formation, $\Delta_{f} H_{0}^{o}$, and the enthalpy of atomization, $\Delta_{a} H_{0}^{o}$, of $\mathrm{Al}_{2} \mathrm{~N}$, the enthalpy changes of the following pressure independent reactions,

$$
\mathrm{C}(\text { graph. })+\mathrm{Al}_{2} \mathrm{~N}(g)+\mathrm{Au}(g)=\mathrm{AlAu}(g)+\mathrm{AlNC}(g),
$$

$$
\mathrm{AlN}(s)+\mathrm{Al}(g)=\mathrm{Al}_{2} \mathrm{~N}(g),
$$

were evaluated according to the third-law method, using the relation $\Delta_{r} H_{0}^{o}=-R T \ln K_{p}-T \Delta\left[\left(G_{T}^{o}-H_{0}^{o}\right) / T\right]$.

The Gibbs energy functions, $\left(G_{T}^{o}-H_{0}^{o}\right) / T\left(\mathrm{GEF}_{0}\right)$, and the heat content functions, $H_{T}^{o}-H_{0}^{o}\left(\mathrm{HCF}_{0}\right)$, needed in the evaluation of the reactions enthalpies were taken from literature for $\mathrm{Al}(g),{ }^{35} \mathrm{AlN}(s),{ }^{35} \mathrm{C}$ (graph.), ${ }^{36} \mathrm{Au}(g),{ }^{37} \mathrm{AlAu},{ }^{34}$ and AINC. ${ }^{20}$ Those for $\mathrm{Al}_{2} \mathrm{~N}(\mathrm{~g})$ were computed according to statistical thermodynamic procedures, using the rigid-rotator harmonic-oscillator approximation ${ }^{38}$ and the molecular constants derived in the present theoretical investigation, bond distance, $r_{\mathrm{Al}-\mathrm{N}}=1.726 \AA$, and bending vibrational mode, $v_{2}$ $=94 \mathrm{~cm}^{-1}$, for which there are no experimental values. For the stretching vibrational modes the experimental values of $v_{1}=545 \mathrm{~cm}^{-1}$ and $v_{3}=957 \mathrm{~cm}^{-1}$ by Andrews et al. ${ }^{8}$ were used. In analogy to $\mathrm{B}_{2} \mathrm{~N},{ }^{27}$ the ${ }^{2} \Sigma_{g}^{+}$excited state with an estimated transition energy $\left(T_{e}\right)$ value of $6000 \mathrm{~cm}^{-1}$ was also considered. Table III lists the thermal functions of $\mathrm{Al}_{2} \mathrm{~N}$.

Reactions (1) and (2) are pressure independent, therefore the measured ion intensities listed in Table III were utilized directly to calculate the equilibrium constant of the reactions (1) and (2), after correcting them for the isotopic abundance, multiplier response and ionization cross sections as described

TABLE III. The Gibbs energy functions, $\left(G_{T}^{v}-H_{0}^{o}\right) / T\left(\mathrm{GEF}_{0}\right)$, in $\mathrm{J} \mathrm{K}^{-1} \mathrm{~mol}^{-1}$, and the heat content functions, $H_{T}^{o}-H_{0}^{o}\left(\mathrm{HCF}_{0}\right)$, in $\mathrm{kJ} \mathrm{mol}^{-1}$. for the $\mathrm{Al}_{2} \mathrm{~N}, \mathrm{AlN}$, and $\mathrm{Al}_{2} \mathrm{~N}_{2}$ molecules.

\begin{tabular}{cccccccc}
\hline \hline & \multicolumn{7}{c}{ Temperature (K) } \\
\cline { 2 - 8 } Species & & 298.15 & 1400 & 1600 & 1800 & 2000 & 2200 \\
\hline $\mathrm{Al}_{2} \mathrm{~N}$ & $-\mathrm{GEF}_{0}$ & 221.0 & 299.2 & 306.7 & 313.5 & 319.6 & 325.2 \\
& $\mathrm{HCF}_{0}$ & 13.21 & 78.57 & 91.08 & 103.7 & 116.4 & 129.3 \\
$\mathrm{AlN}$ & $-\mathrm{GEF}_{0}$ & 198.9 & 250.7 & 255.4 & 259.6 & 263.4 & 266.9 \\
& $\mathrm{HCF}_{0}$ & 9.264 & 49.68 & 57.18 & 64.70 & 72.23 & 79.78 \\
$\mathrm{Al}_{2} \mathrm{~N}_{2}$ & $-\mathrm{GEF}_{0}$ & 239.5 & 334.2 & 344.0 & 352.9 & 361.0 & 368.5 \\
& $\mathrm{HCF}_{0}$ & 14.72 & 101.6 & 119.3 & 137.2 & 155.3 & 173.4 \\
\hline \hline
\end{tabular}


in Ref. 20. The multiplier gain, $\gamma$, for $\mathrm{Al}_{2} \mathrm{~N}$ was measured with a $50 \%$ transmission grid as $10^{5}$ times 3.87 . The relative ionization cross sections, $\sigma$, in $10^{-16} \mathrm{~cm}^{2}$, used were at $30 \mathrm{eV}: \mathrm{Al}_{2} \mathrm{~N}, 15.2$ as $0.75 \times\left(2 \sigma_{\mathrm{Al}}+\sigma_{\mathrm{N}}\right)$, where $\sigma_{\mathrm{Al}}$ and $\sigma_{\mathrm{N}}$ were taken from Freund et al. ${ }^{39}$ and Brook et al. ${ }^{40}$ respectively; and at $15.5 \mathrm{eV}$ : $\mathrm{Al}, 9.27 ;^{39} \mathrm{Au}, 3.10 ;{ }^{41} \mathrm{C}, 0.70 ;{ }^{40} \mathrm{~N}$, $0.25 ;{ }^{40} \mathrm{Al}_{2} \mathrm{~N}, 14.1$ as $0.75 x\left(2 \sigma_{\mathrm{Al}}+\sigma_{\mathrm{N}}\right) ; \mathrm{AlAu}, 9.28$ as $0.75 x\left(\sigma_{\mathrm{Al}}+\sigma_{\mathrm{Au}}\right)$; AlNC, 7.66 as $0.75 x\left(\sigma_{\mathrm{Al}}+\sigma_{\mathrm{N}}+\sigma_{\mathrm{C}}\right)$.

The literature values for the enthalpies of formation, $\Delta_{f} H_{0}^{o}$, in $\mathrm{kJ} \mathrm{mol}^{-1}$, used to obtain the final values for the enthalpy of formation and atomization of $\mathrm{Al}_{2} \mathrm{~N}$ were: 368.0 $\pm 1.3{ }^{37} 711.2 \pm 0.5,^{36} \quad 470.8 \pm 0.1,^{36} 327.6 \pm 3.0,^{35}-341.3$ $\pm 3.0{ }^{35} 372.9 \pm 8.4,{ }^{34} 281.3 \pm 14,{ }^{20}$ for $\mathrm{Au}(g), \mathrm{C}(g), \mathrm{N}(g)$, $\operatorname{Al}(g), \operatorname{AlN}(s), \operatorname{AlAu}(g)$, and $\operatorname{AlNC}(g)$, respectively. From the $\Delta_{r} H_{0}^{o}$ values, see Table III, and these auxiliary literature data the respective $\Delta_{f} H_{0}^{o}$ and $\Delta_{a} H_{0}^{o}$ were derived, using the following relations: for reaction (1), $\Delta_{f} H_{0}^{o}\left(\mathrm{Al}_{2} \mathrm{~N}, g\right)$ $=\Delta_{f} H_{0}^{o}(\mathrm{AlAu}, g)+\Delta_{f} H_{0}^{o}(\mathrm{AlNC}, g)-\Delta_{f} H_{0}^{o}(\mathrm{Au}, g)$ $-\Delta_{r} H_{0}^{o}$ and $\Delta_{a} H_{0}^{o}\left(\mathrm{Al}_{2} \mathrm{~N}, g\right)=2 \Delta_{f} H_{0}^{o}(\mathrm{Al}, g)+\Delta_{f} H_{0}^{o}(\mathrm{~N}, g)$ $-\Delta_{f} H_{0}^{o}\left(\mathrm{Al}_{2} \mathrm{~N}, g\right)$; for reaction (2), $\Delta_{f} H_{0}^{o}\left(\mathrm{Al}_{2} \mathrm{~N}, g\right)=\Delta_{r} H_{0}^{o}$ $+\Delta_{f} H_{0}^{o}(\mathrm{Al}, g)+\Delta_{f} H_{0}^{o}(\mathrm{AlN}, s)$.

By giving the same weight to both reactions employed in the present investigation we obtain the values, in $\mathrm{kJ} \mathrm{mol}^{-1}$ : $783.2 \pm 15,790.0 \pm 15,342.8 \pm 15$, and $342.7 \pm 15$ for $\Delta_{a} H_{0}^{o}$, $\Delta_{a} H_{298.15}^{o}, \Delta_{f} H_{0}^{o}$, and $\Delta_{f} H_{298.15}^{o}$ of $\mathrm{Al}_{2} \mathrm{~N}(g)$, respectively. Here the uncertainties are the overall errors obtained as discussed in Schmude et al. ${ }^{42}$ Our computed $\Delta_{a} H_{0}^{o}\left(\mathrm{Al}_{2} \mathrm{~N}, g\right)$ of $731 \mathrm{~kJ} \mathrm{~mol}^{-1}$ or $7.58 \mathrm{eV}$ is about $7 \%$ smaller than the experimental value of $783.2 \mathrm{~kJ} \mathrm{~mol}^{-1}$; the value of 758 $\mathrm{kJ} \mathrm{mol}^{-1}$ or $7.86 \mathrm{eV}$ from Nayak et al., ${ }^{11}$ obtained using the generalized gradient approximation (GGA) level of theory, is about 3\% smaller than our experimental value. The value of $728 \mathrm{~kJ} \mathrm{~mol}^{-1}$ or $7.55 \mathrm{eV}$ by Andrews et al. ${ }^{8}$ based on B3LYP/cc-pVDZ calculations without ZPE correction practically coincides with our computed value.

The early $\Delta_{a} H_{0}^{o}\left(\mathrm{Al}_{2} \mathrm{~N}, g\right)$ of $822 \pm 21 \mathrm{~kJ} \mathrm{~mol}^{-1}$ (Ref. 6) differs from our result because of the different assumptions in the thermal functions used and of the different partial pressures obtained in the two investigations. A representative example of this difference is given for reaction (1) at $1940 \mathrm{~K}$. At this temperature the difference of the $\triangle \mathrm{GEF}_{0}$ used in this study and those in Ref. 6 is $5.9 \mathrm{~J} \mathrm{~mol}^{-1} \mathrm{~K}^{-1}$, and $\ln K_{p}$ obtained in this investigation is 0.8 higher than $\ln K_{p}$ in Ref. 6. These differences reflect on an increase of the enthalpy change of reaction (1) for Ref. 6 of about $24 \mathrm{~kJ} \mathrm{~mol}^{-1}$, and thus the corresponding atomization energy is lowered by the same amount. The corrected value of $798 \pm 21 \mathrm{~kJ} \mathrm{~mol}^{-1}$ is within the error limits of the present investigation.

\section{AIN}

During the mass spectrometric measurements the species $\mathrm{AlN}^{+}$was detected several times. Its IE value of 15.8 $\pm 0.6 \mathrm{eV}$, obtained from the linear extrapolation method, was relatively large due to fragmentation of the parent molecule AINC. ${ }^{20}$ In order to reduce the fragmentation contribution to $\mathrm{AlN}^{+}$we measured the ion intensity of AIN with $13 \mathrm{~V}$ electrons as $7.8 E-14 \mathrm{~A}$, whereas the ion intensity of $\mathrm{AlNC}^{+}$, involved in one of the reactions used, measured at $30 \mathrm{eV}$ (see
Table II, Series 1) was corrected to $13 \mathrm{eV}$ as $5.7 E-9 \mathrm{~A}$ using its ionization efficiency curve (IEC). At these experimental conditions the ion current of AlN is $2 \%$ of that one of $\mathrm{Al}_{2} \mathrm{~N}, 4.0 \mathrm{E}-12 \mathrm{~A}$, and there could still be a fragmentation contribution caused from $\mathrm{Al}_{2} \mathrm{~N}$. The following reactions have been evaluated: $\operatorname{AIN}(g)+\mathrm{C}($ graph. $)=\operatorname{AINC}(g)$ and $\operatorname{AlN}(s)=\operatorname{AlN}(g)$, according to the third-law method.

The $\mathrm{GEF}_{0}$ and $\mathrm{HCF}_{0}$ for $\operatorname{AlN}(g)$, needed in the evaluation of the reactions enthalpies, were calculated using the vibrational frequency of $747 \mathrm{~cm}^{-1}$ and the bond distance of $1.786 \AA$, by Simmons and McDonald. ${ }^{7}$ Two excited electronic states and respective energies, in $\mathrm{cm}^{-1}$, based on theoretical computations of Langhoff et al. ${ }^{10}$ were also taken into account: ${ }^{3} \Sigma^{-}(378),{ }^{1} \Sigma^{+}(4689)$. Table III lists the thermal functions of AlN.

The relative ionization cross sections, $\sigma$, in $10^{-16} \mathrm{~cm}^{2}$, used at $13 \mathrm{eV}$ were: $\mathrm{Al}, 8.47 ; 3^{39} \mathrm{C}, 0.267 ;{ }^{40} \mathrm{~N}, 0.092 ;{ }^{40} \mathrm{AIN}$, 6.42 as $0.75 x\left(\sigma_{\mathrm{Al}}+\sigma_{\mathrm{N}}\right)$; and AlNC, 6.62 as $0.75 x\left(\sigma_{\mathrm{Al}}\right.$ $+\sigma_{\mathrm{N}}+\sigma_{\mathrm{C}}$ ). The multiplier gain of AlN was estimated to be $10^{5}$ times 4.

The $\Delta_{r} H_{0}^{o}$ values, in $\mathrm{kJ} \mathrm{mol}^{-1}$, obtained were -141 and 754. From these and auxiliary literature data, the $\Delta_{a} H_{0}^{o}$ values, in $\mathrm{kJ} \mathrm{mol}^{-1}$, were derived as 377 and 359 , the average value being $\Delta_{a} H_{0}^{o}(\mathrm{AlN}, g)=(368 \pm 15) \mathrm{kJ} \mathrm{mol}^{-1}$, or $(3.80$ $\pm 0.16) \mathrm{eV}$. The corresponding theoretical values, in $\mathrm{eV}$, are: 2.60 (B3LYP); ${ }^{8} \quad 2.35$ (MRCI); ${ }^{10} 3.54$ (LSDA); $;^{11} 2.78$ $(\mathrm{GGA}) ;^{11} 2.45 \quad(\mathrm{CCSD}(\mathrm{T})) ;^{14} 2.44 \quad(\mathrm{G} 2) ;^{15}$ and 2.59 (CBS-RAD). ${ }^{15}$ Chase et al. ${ }^{36}$ estimated the $D_{0}^{o}(\mathrm{AlN}, g)$ of $(2.85 \pm 0.37) \mathrm{eV}$ from spectroscopic evidence.

Our upper limit for the dissociation energy of AlN is markedly higher than these computed values, except for the LSDA value; it is, however, consistent with the experimental values, in $\mathrm{eV}$, for the isoelectronic molecules $\mathrm{BP}$ (3.56 $\pm 0.18),{ }^{43} \mathrm{MgO}(3.47 \pm 0.26),{ }^{36}$ and $\mathrm{BeS}(3.63 \pm 0.21),{ }^{35}$ which are somewhat lower, and with that of $\mathrm{SiC}(4.48$ $\pm 0.22),{ }^{44}$ which is higher. Isoelectronic molecules are known to often have similar atomization energies. Our upper limit value definitely shows that the dissociation energy of AlN is smaller than that of SiC.

The Gaussian-2 (G2) value of Swihart band Catoire ${ }^{15}$ is considerably lower than our upper limit. The G2 method is commonly thought reliable to within $\pm 8.4 \mathrm{~kJ} \mathrm{~mol}^{-1}$, ${ }^{45}$ but as Schulz et al. ${ }^{46}$ showed, results from G2 method can be very inaccurate in determining the thermodynamic properties of small polar metal-containing species. The reasons of this inaccuracy can be several, such as relaxation of inner-valence orbitals ${ }^{46}$ additivity approximation of energies, ${ }^{46}$ and spin contamination. ${ }^{47}$

A decision whether, e.g., the $\mathrm{G} 2$ theoretical value is accurate or whether our estimated upper limit is closer to the actual dissociation energy should come from new advanced spectroscopic measurements.

\section{$\mathrm{Al}_{2} \mathrm{~N}_{2}$}

From a sensitive test to detect the $\mathrm{Al}_{2} \mathrm{~N}_{2}$ molecule, we could estimate an upper limit of its ion intensity as $4 E-14 \mathrm{~A}$ at $1940 \mathrm{~K}$ with $30 \mathrm{~V}$ electrons. For the determination of an upper limit of the enthalpy of atomization, $\Delta_{a} H_{0}^{o}$, of $\mathrm{Al}_{2} \mathrm{~N}_{2}$ 
we evaluated the pressure independent reaction $2 \mathrm{Al}_{2} \mathrm{~N}(\mathrm{~g})$ $+\mathrm{Au}(g)=\mathrm{Al}_{2} \mathrm{~N}_{2}(g)+\mathrm{AlAu}(g)+\mathrm{Al}(g)$, according to the third-law method.

The ion currents for the other reactants are given in Table II, Series 1. The thermal functions, $\mathrm{GEF}_{0}$ and $\mathrm{HCF}_{0}$, for $\mathrm{Al}_{2} \mathrm{~N}_{2}(g)$ were computed using the molecular constants derived by Boo and $\mathrm{Liu}^{13}$ at the $\operatorname{CCSD}(\mathrm{T}) / \mathrm{cc}-\mathrm{pVTZ} / \mathrm{MP} 2 /$ cc-pVDZ level of theory for the ${ }^{1} A_{g}\left(D_{2 h}\right)$ rhombic structure. The linear AlNNAl structure with a ${ }^{3} \Sigma_{g}^{-}$state by 50 $\mathrm{kJ} \mathrm{mol}^{-1}$ above the ground state was also considered. Table III lists the resulting thermal functions of $\mathrm{Al}_{2} \mathrm{~N}_{2}$. The relative ionization cross section, in $10^{-16} \mathrm{~cm}^{2}$, at $30 \mathrm{eV}$ for $\mathrm{Al}_{2} \mathrm{~N}_{2}$ was taken as 15.9, as $0.75 x\left(2 \sigma_{\mathrm{Al}}+2 \sigma_{\mathrm{N}}\right)$.

The resulting $\Delta_{r} H_{0}^{o}$ was equal to $-127 \mathrm{~kJ} \mathrm{~mol}^{-1}$ and, using the auxiliary literature data listed above, the upper value of $\Delta_{a} H_{0}^{o}\left(\mathrm{Al}_{2} \mathrm{~N}_{2}, g\right)$ was derived as $1402 \mathrm{~kJ} \mathrm{~mol}^{-1}$. This value compares with the value of $1117 \mathrm{~kJ} \mathrm{~mol}^{-1}$ calculated by Andrews et al. ${ }^{8}$ and with the value of $1070 \mathrm{~kJ} \mathrm{~mol}^{-1}$ by Boo and Liu. ${ }^{13}$ The latter value has been obtained using the total energy of $\mathrm{Al}_{2} \mathrm{~N}_{2}$, including the $\mathrm{ZPE}$, given by Boo and $\mathrm{Liu}$ and the relative total energies of $\mathrm{Al}$ and $\mathrm{N}$, computed by us at the same level of theory, $\operatorname{CCSD}(\mathrm{T}) / \mathrm{cc}-\mathrm{pVTZ}$, used by Boo and Liu. The computed total energies, in hartree, are -241.9312036 for $\mathrm{Al}$, and -54.5147074 for $\mathrm{N}$.

The failure of detecting gaseous $\mathrm{Al}_{2} \mathrm{~N}_{2}$ is consistent with the available theoretical predictions, but it is difficult to reconcile with the report of Gordienko et al. ${ }^{48}$ that gallium nitride vaporized from an open crucible mainly in the form of dimers, $\mathrm{Ga}_{2} \mathrm{~N}_{2}$. Specifically, it is concluded that the observation of Gordienko et al. ${ }^{48}$ cannot correspond to equilibrium conditions among the vapor species above solid GaN.

\section{ACKNOWLEDGMENTS}

$A b$ initio calculations were performed on a workstation (Power Challenge, Silicon Graphics with twelve R10000 CPUs) in the Department of Chemistry at Texas A\&M University, supported by NSF Grant No. CHE-9528196. The authors wish to thank the Robert A. Welch Foundation for financial support of this work.

${ }^{1}$ F. A. Ponce and D. P. Bour, Nature (London) 386, 351 (1997).

${ }^{2}$ J. Hermann and C. Dutouquet, J. Phys. D 32, 2707 (1999).

${ }^{3}$ L. M. Sheppard, Ceram. Bull. 69, 1801 (1990).

${ }^{4}$ T. J. Mroz, Jr., Ceram. Bull. 70, 849 (1991).

${ }^{5}$ A. Bhatti. H. S. Al-Raweshidy, and G. Murtaza, Opt. Commun. 176, 355 (2000).

${ }^{6} \mathrm{~K}$. A. Gingerich, Chem. Commun. 1970, 441.

${ }^{7}$ J. D. Simmons and J. K. McDonald, J. Mol. Spectrosc. 41, 584 (1972).

${ }^{8}$ L. Andrews, M. Zhou, G. V. Chertihin, W. D. Bare, and Y. Hannachi, J. Phys. Chem. A 104, 1656 (2000).

${ }^{9}$ M. Pelissier and J. P. Malrieu, J. Mol. Spectrosc, 77, 322 (1979).

${ }^{10}$ S. R. Langhoff, C. W. Bauschlicher, Jr., and L. G. M. Pettersson, J. Chem. Phys. 89, 7354 (1988).

"S. K. Nayak, S. N. Khanna, and P. Jena, Phys. Rev. B 57, 3787 (1998).

12 J. J. BelBruno, Chem. Phys. Lett. 313, 795 (1999).

${ }^{13}$ B. H. Boo and Z. Liu, J. Phys. Chem. A 103, 1250 (1999).

${ }^{14}$ G. L. Gutsev, P. Jena, and R. J. Barlett. J. Chem. Phys. 110, 2928 (1999).
${ }^{15}$ M. T. Swihart and L. Catoire, Combust. Flame 121, $210(2000)$.

${ }^{16}$ A. K. Kandalam, R. Pandey, M. A. Blanco, A. Costales, J. M. Recio, and J. M. Newsam, J. Phys. Chem. B 104, 4361 (2000).

${ }^{17}$ R. Viswanathan, R. W. Schmude, Jr., and K. A. Gingerich, J. Chem. Thermodyn. 27, 1303 (1995).

${ }^{18}$ K. A. Gingerich, R. Viswanathan, and R. W. Schmude, Jr., J. Chem. Phys. 106, 6016 (1997).

${ }^{19} \mathrm{M}$. Sai Baba, R. Viswanathan, and K. A. Gingerich, in Proceedings of the IX International Conference on High Temperature Materials Chemistry, edited by K. E. Spear (The Electrochemical Society, Pennington, 1997). Vol. 97-39, p. 689

${ }^{20}$ G. Meloni and K. A. Gingerich, J. Chem. Phys. 111, 969 (1999).

${ }^{21}$ G. Meloni, R. Viswanathan, and K. A. Gingerich, J. Chem. Phys. 111. 9325 (1999).

${ }^{22}$ M. J. Frisch, G. W. Trucks, H. B. Schlegel et al., Gaussian 98, Revision A.6 (Gaussian, Inc., Pittsburgh, PA, 1998).

${ }^{23}$ F. R. Omellas and S. Iwata, J. Phys. Chem. 100, 10919 (1996).

${ }^{24}$ D. J. Brugh and M. D. Morse, Chem. Phys. Lett. 267, 370 (1997).

${ }^{25}$ L. B. Knight, Jr., D. W. Hill, T. J. Kirk, and C. A. Arrington, J. Phys. Chem. 96. 555 (1992).

${ }^{26}$ K. R. Asmis, T. R. Taylor, and D. M. Neumark, Eur. Phys. J. D 9. 257 (1999).

${ }^{27}$ K. R. Asmis, T. R. Taylor, and D. M. Neumark, J. Chem. Phys. 111, 8838 (1999).

${ }^{28}$ J. M. L. Martin. J. P. Francois, and R. Gijbels, Chem. Phys. Lett. 193, 243 (1992).

${ }^{29}$ J. S. Robinson, A. J. Apponi, and L. M. Ziurys, Chem. Phys, Lett. 278, I (1997).

${ }^{30}$ I. Gerasimov, X. Yang, and P. J. Dagdigian, J. Chem. Phys. 110, 220 (1999).

${ }^{31} \mathrm{~K}$. A. Gingerich. in Current Topics in Materials Science, edited by E. Kaldis (North-Holland, Amsterdam. 1980), Vol. 6, p. 345.

${ }^{32}$ C. E. Moore, NSRDS-NBS 35. Natl. Bur. Stand. U.S., 1971.

${ }^{33}$ J. W. Warren, Nature (London) 165, 810 (1950).

${ }^{34}$ K. A. Gingerich and G. D. Blue, J. Chem. Phys. 59. 185 (1973).

${ }^{35}$ Thermodynamic Properties of Individual Substances, edited by L. V. Gurvich, I. V. Veyts, and C. B. Alcock (Begell House, New York, 1996), Vol. 3.

${ }^{36}$ M. W. Chase, Jr., C. A. Davies, J. R. Downey, Jr., D. J. Frurip, R. A. Mc Donald, and A. N. Syverud, JANAF Thermochemical Tables, 3rd ed., edited by D. R. Lide, Jr. (American Institute of Physics. New York. 1986).

${ }^{37}$ R. Hultgren, P. D. Desai, D. T. Hawkins, M. Gleiser. K. K. Kelly, and D. D. Wagman, Selected Values of the Thermodynamic Properties of the Elements (American Society for Metals, Metals Park. 1973).

${ }^{38}$ D. K. Stull and H. Prophet, in Characterization of High Temperature Vapors, edited by J. L. Margrave (Wiley-Interscience, New York, 1971), p. 359.

${ }^{39}$ R. S. Freund, R. C. Wetzel, R. J. Shul, and T. R. Hayes, Phys. Rev. A 41. 3575 (1990).

${ }^{40}$ E. Brook, M. F. A. Harrison. and A. C. H. Smith, J. Phys. B 11, 3115 (1978).

${ }^{41}$ J. B. Mann, in Recent Developments in Mass Spectrometry, edited by K. Ogata and T. Hayakawa (University Park, Tokyo, 1970), p. 814.

${ }^{42}$ R. W. Schmude, Jr., Q. Ran, and K. A. Gingerich. J. Chem. Phys. 99. 7998 (1993).

${ }^{43}$ K. A. Gingerich, J. Chem. Phys. 56, 4239 (1972).

${ }^{44}$ K. A. Gingerich, R. W. Schmude, Jr., and M. Sai Baba, in Proceedings of the IX International Conference on High Temperature Materials Chemistry, edited by K. E. Spear (The Electrochemical Society, Pennington, 1997), Vol. 97-39, p. 629.

${ }^{45}$ L. A. Curtiss, K. Raghavachari, G. W. Zrucks, and J. A. Pople, J. Chem. Phys, 94, 7221 (1991).

${ }^{46}$ A. Schulz, B. J. Smith, and L. Radom, J. Phys. Chem. A 103, 7522 (1999),

${ }^{47}$ P. M. Mayer, C. J. Parkinson, D. M. Smith, and L. Radom, J. Chem. Phys. 108, 604 (1998),

${ }^{48}$ S. P. Gordienko, G. V. Samsonov, and V. V. Fesenko, J. Phys. Chem. 38. 1620 (1964). 
The Journal of Chemical Physics is copyrighted by the American Institute of Physics (AIP). Redistribution of journal material is subject to the AIP online journal license and/or AIP copyright. For more information, see http://ojps.aip.org/jcpo/jcpcr/jsp 